\title{
Emptiness and Nothingness in OMA's Libraries
}

\author{
OMA'in Kütüphanelerinde Boșluk ve Yokluk
}

\author{
• Onur ŞIMŞEK
}

\section{ABSTRACT}

This paper aims to analyse the semantical paralells between the philosophical meaning of the terms nothingness and emptiness as they were used by the presocratic philosophers Parmenides and Democritos and the meaning of nothingness and emptiness in the theory and praxis of Rem Koolhaas. First the philosophical context where Parmenides and Democritus used the terms will be explained and the role, which these terms played in the prehistoric cosmovision will be underlined. Then these terms will be compared with some texts of Koolhaas, in which the very same terms play a major role. Further Koolhaas' concept will be analysed at two libraries, namely the Seattle Central Library and the Très Grande Bibliothèque in Paris.

Keywords: Architecture; design; emptiness; Koolhaas; library; nothingness; OMA; philosophy.

Öz

Bu makalenin amacı Sokrat öncesi felsefede önemli olan yokluk ve boşluk kavramlarını günümüz mimarlarından Rem Koolhaas'ın teori ve projelerindeki kullanışlarıyla karşılaştırmaktır. Parmenides ve Demokritos `un yokluk ve boşluk kavramlarını kullandıkları felsevi çerçeve açıklandıktan sonra Koolhaas'ın teroisinde aynı kavramlar analiz edilerek felsefeden mimarlığa uzanan semantik bir karşılaştırma denenecektir. Teorik analizlerin ardından OMA'in Seattle Library ve Paris Très Grande Bibliothèque projelerinde bu kavramların merkezinde oluşturulan konsept ve tasarımdaki pratik çıktısı irdelenecektir.

Anahtar sözcükler: Mimarlık; tasarım; boşluk; Koolhaas; kütüphane; yokluk; OMA; felsefe. 


\section{Introduction}

\section{Imagining Nothingness}

"Where there is nothing, everything is possible. Where there is architecture, nothing (else) is possible." ${ }^{1}$

Although the writer of this paper is convinced that Koolhaas as an eloquent author likes the pretentious esthetics of dialectic rhetoric more than thinking and talking like a philosopher, this paper aims to analyse the philosophical base of the upper citation and its projection in Koolhaas' work, namely in the Seattle Central Library and the Très Grande Bibliothèque in Paris. The design approaches of these buildings are critically important for my study because these buildings display certain reflexions of the mentioned rhetoric of Koolhaas, namely the idea of void. Further they constitute with their concepts important roles if not cornerstones within OMA's (Office for Metropolitan Architecture) design repertoire. In further projects of OMA the same design approaches or varities of the void concept find place. This demonstrates, that the use of words like void / absence / nothing in OMA's texts is also embedded in the design of numerous projects.

The discussion about emptiness and nothingness started in the history of Western Philsophy with Democritos and Parmenides. While Parmenides drew with "nothing" the verbal border, Democritos concept of "emptiness" enabled again the discussion of beeings counterpart, the understanding of space in which the atoms move. This paper displays that Koolhaas does not use the popular terminology of the philosophers Parmenides and Democritos as pure rhetoric but constructs mometropolitan affinities to his idea of emptiness. It is interesting that there are strong parallelities, between Demokritos' cosmovision and Koolhaas' reading of contemporary architectural problems and design methods. Koolhaas' theoretical approach with the terms like void, nothing, absence, emerge in the design process of OMA as "carving out" and "leaving over", which became, from the point of author's view, important in different ways for the work of OMA.

Further potential of the following analysis bases on the fact that the terms nothingness and emptiness enable to understand architecture beyond the built and constructed space. The suggested perspective opens on one hand new chances to keep a certain dynamism in metropoles inspite of the immense density problems. By analysing OMA's theory and design approach the aim of this analysis is also to find the answer of following research question:

Does the combination of philosophical terminology with spatial analysis contribute to the field of architecture?

Koolhaas, 1995, p. 199.

\section{Being and Absence by Parmenides}

Parmenides, one of the pre-Socratic philosophers with an appreciable influence for the time after, starts his teaching in his renowned didactic poem "on nature" with the annotation, that human thinking is depending on the capacity of perception. "The first, namely, that it is, and that it is impossible for anything not to be." ${ }^{2}$

Further on Parmenides combines existence with the field of thinking: "For it is the same thing that can be thought and that can be." ${ }^{3} \mathrm{He}$ is so convinced about his theory, that further Parmenides' teaching becomes a postulation: "One path only is left for us to speak of, namely, that it is." ${ }^{4}$ For him humans can only think and hence talk about what can be perceived. With this formula Parmenides aims to avoid discussions leading into the void. It is only possible to think and talk about anything, that is, and it is impossible to think and talk about anything, that is not. Being, which has for Parmenides no beginning, is the only field of thought, where human can be productive and consistent in the philosophical sense. It is only possible to talk about the reason of something, that is not or why it is not existing but not about its absence itself.

But instead of Parmenides influence to the analytic philosophy it is useful for this text to look at Demokritos, who substitutes Parmenides' absence with the term emptiness, which is a considerable step in the sense of extending the field of thinking.

\section{Emptiness by Demokritos}

As written before, Parmenides defines absence as a field, which cannot be captured in philosophical sense. Demokritos uses the "absence" concept of Parmenides and develops "emptiness" out of this term, which is necessary for the motion of atoms. For Demokritos, motion cannot be understood without emptiness. This thought gives emptiness a central role in the existence of the universe. ${ }^{5}$

For Demokritos emptiness is not like the atoms but still as existent as the atoms. Emptiness does not need the atoms to exist but the atoms instead need emptiness to be able to get in motion. In Demokritos' existence-philosophy, emptiness is as important as the atoms. Emptiness is composed of empty elements and therefore enables motion. Emptiness will be filled with the active atoms.

Demokritos' cosmology is based on two elements: atoms and emptiness. Atoms do not have any inherent motion, so they cannot fall in separation. They experience outer motion. Demokritos uses the term emptiness as a

\footnotetext{
2 http://philoctetes.free.fr/parmenides.pdf, P. 1, 02.10.2011.

3 http://philoctetes.free.fr/parmenides.pdf, P. 2, 02.10.2011.

4 http://philoctetes.free.fr/parmenides.pdf, P. 2, 02.10.2011.

5 http://www.flsfdergisi.com/sayi7/107-120.pdf 31.09.2011.
} 


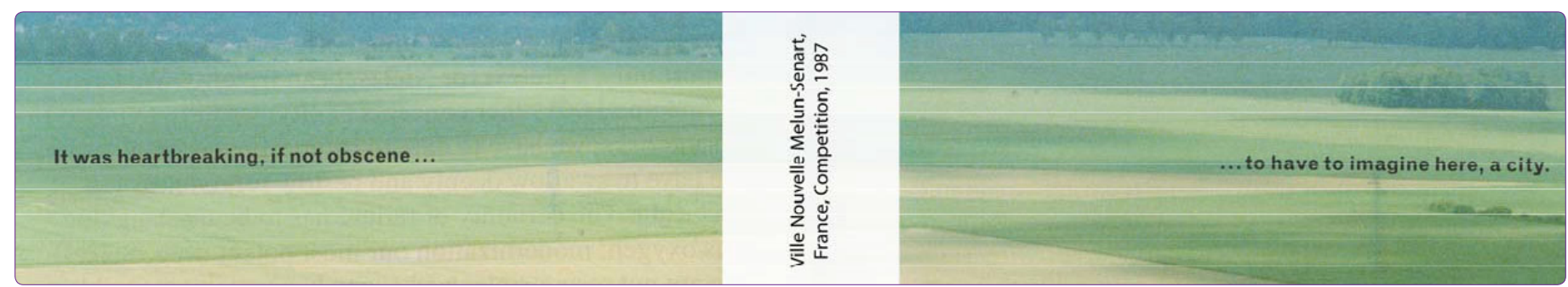

Figure 1. Surrender.

linguistic skin to nothingness and amplifies through it the basic of his theory about motion.

\section{Nothingness/Emptiness/Void/Absence by Koolhaas}

In the vocabulary of Rem Koolhaas and his Office for Metropolitan Architecture the words emptiness, void and absence appear for the same or similar meanings. In theory and praxis, in different projects, scales or forms they target the definition of architectural space. We face void as the negative of the built mass, which is also described by Koolhaas as the "absense of the built." The term emptiness replaces void in some descriptions without charging a different meaning. Nothingness as an umbrella term in this context is the result of the absence of architecture. By using the word nothingness as the outcome of eliminating architecture Koolhaas opens new possibilites for architectural program. Nothingness defines a created architectural program without the necessity of construction. By using this word together with "imagining" a rhetorical allusion to Parmenides appears. But if nothingness also defines architectural space as a created program, the term nothingness shows equivalency to the term emptiness. While Democritos used the term emptiness for the space in which the atoms can move, Rem Koolhaas uses emptiness for the architectural space which also enables movement, namely the movement of the users. Before continuing with the analysis of Koolhaas works it shoud be mentioned that this vocabulary, used by Rem Kollhaas enables to understand architecture the other way around, namely with the definition of what architecture is not or with the opposite of the built.

\section{Imagining Nothingness}

Rem Koolhaas introduces his essay from 1985 with an ambitious, more rhetorical than philosophical, formula:

"Where there is nothing, everything is possible. Where there is architecture, nothing (else) is possible." ${ }^{6}$

By understanding this citation literally, one could think, that Koolhaas determines for architecture a black holerole, which is denying every other existence or in other words, which is existing to effect absence. Architecture

6 Koolhaas, 1995, p. 199 seems not only to occupy the background but also the empty space where any atom could get in motion (Fig. 1).

Koolhaas writes in his essay: "Maybe architects' fanaticism...is not merely a professional deformation but a response to the horror of architecture's opposite, an instinctive recoil from the void, a fear of nothingness." ${ }^{\prime 7}$ If architecture can be understood as human's effort of designing or shaping their surrounding, ${ }^{8}$ Koolhaas asks the architects not to do architecture and not to use their pens until the last white point on the plan inherits a vision.

How can this be understood from the founder of an office named OMA (Office for Metropolitan Architecture)? Is Koolhaas for more nature and less polis? Although Parmenides dictates only to talk about what is, Koolhaas is not only talking about nothing, he aspires or even desires to imagine, to plan and further to program nothingness.

Architecture enclosures programs, which are generated out of the complexity of living (as a XL magnitude in the city), intended by human beings. Since cities designate the social transmission from nomadism to settledness and stand for prosperity, education, security, the quantity and density of programs in the metropolitan life extand ad infinitum. At an urban scale the fondness to erase void by shaping and "the fear of nothingness" is a consequence of failed city politics, uncontrolled densities and absent urban transformations. While architects of the last century simulated omnipotence in planning and organizing metropolises, the unexpected challenges, which architects face in every continent today, divulged the impotence of bringing the city-phenomenon under control. While new programs and areas wait for being built, architecture in other (not irrelevant) parts of the city, waits for program.

At the beginning of his essay, Koolhaas diagnoses a problem of the metropolises, which he demonstrates with the example of Berlin. Koolhaas asserts that large areas of the city are not needed anymore and it is hopeless trying to keep them alive by urban reconstruction. Koolhaas suggests another strategy:

"What is necessary instead is to imagine ways, in which density can be maintained without recourse to substance, intensity without the encumbrance of architecture." ${ }^{\prime 9}$ The

Koolhaas, 1995, p. 200. ${ }^{8}$ Cansever, 2009, p. 16. ${ }^{9}$ Koolhaas, 1995, p. 200. 
pioneers of the urban volume problem of the city are the historic centers, which for Koolhaas mask the reality of the "un-city."

"Through the parallel actions of reconstruction and deconstruction, such a city becomes an archipelago of architectural islands floating in a post-architectural landscape of erasure where there was once a city is now a highly charged nothingness." ${ }^{10}$

"Highly charged nothingness" means for Koolhaas islands full of "architecture" and architectural work like de-and reconstruction, but devoid of coherent program, operating metabolism, animated mass or aggregated identity. The description "Highly charged nothingness" discloses the absence of two aspects:

The loss of identity and the tendency of programmatic isolation in spite of physical presence. The first aspect points on existing urban areas, which have lost their meaning and importance for the city but still exist in an incoherent relation to the current urban fabric in spite of the shrinking inhabitation. The relation of the mass to the productive effective program is marginal. The necessity of these areas has to be questioned. To enhance the density of these areas, reconstructions will be implemented. Koolhaas classifies this strategy as improper or even desperate:

"In these circumstances, the blanket application of urban reconstruction may be as futile as keeping brain-dead patients alive with medical apparatus." ${ }^{\prime 1}$ In Democrit's vocabulary, this would equal the intention, trying to animate the atoms, by constraining their action field. This would contradict the principle idea, that atoms need emptiness to be able to move. In this manner Koolhaas suggestion is completely comprehensible and accordant to the philosophy of Democrit.

The second chapter "Nevada" starts with the same tone of tragic declaration. The problem is described in a literate, actually emotional diction which intensifies the impact of his proposal for solution. "It is a tragedy that planners only plan and architects only design more architecture." ${ }^{12}$ Instead of designing architecture, Koolhaas suggests "liberty zones", conceptual Nevadas, the exploration and cultivation of nothingness and summarizes:

"Imagining nothingness is: Pompeii - a city built with the minimum of walls and roofs...Central Park - a void that provoked the cliffs that now define it... Hilberheimer's "Mid West" with its vast plains of zero-degree architecture......They all reveal that emptiness in the metropolis is not empty, that each void can be used for programs whose insertation into the existing texture is a procrustean effort leading to mutilation of both activity and texture." ${ }^{13}$

\footnotetext{
${ }^{10}$ Koolhaas, 1995, p. 201.
}

${ }^{11}$ Koolhaas, 1995, p. 201.

\footnotetext{
12 Koolhaas, 1995, p. 201.

${ }^{13}$ Koolhaas, 1995, p. 202.
}

In the last sentence of his writing, the parallelism to Democritos is becoming evident. The inconspicuous castling of the terms void and emptiness in the last sentence reflects their equivalency within Koolhaas' formula. As it is known, that Koolhaas often articulates his architectural thoughts and praxis within contradictions like stupid but smart, cheap but expensive,... imagining nothingness can be catogorized in the same rubric of the Koolhaas-citates-antology. More than controverting Parmenides demand "One path only is left for us to speak of, namely, that It is," Koolhaas constructs a logical impossibility, which he then solves like Democritos by the implementation of the term emptiness. A second explanation is also possible: Nothingness is standing for the methodology of exclusion, the ethics of abstinence. This statement becomes clearer if one looks at Koolhaas definition of architectural profession. The abstinence of defining or more challenging the role of architects and architecture he enables himself to refer on different disciplines or methods. The cautious definition of his profession enriches the number of possibilities and legitimises experiments. As it is important for Koolhaas to create "interesting montages" the quantity of possibilities becomes evident. The abstinence in definition effects and enables the bravery in the design process. While nothingness is marking the method, emptiness is standing for the requested result and coevally for the desired point of origin. It is the requested result as is claimed to abstain from planning and filling the city full with substance in other words with architecture. It is the desired point of origin which enables programmatic adaptations and enhancing the animation of urban qualities. Hereby the fine difference as well as the analogy between nothingness and emptiness within Koolhaas' diction is explained.

In summary not only the vocabularies of Democrit and Koolhaas are similar. There are intense parallels in their conceptions. Koolhaas pleads the necessity of emptiness in cities in order to revive for instance the city center, while for Democritos emptiness is the inevitable existence which enables the movement of being in micro scale.

\section{Seattle Central Library}

\section{Overview of Design Concept}

Apart from the unsatisfactory quantity Rem Koolhaas has built in America, as an architect coming from script writing, he seems to be potentially the perfect architectural protagonist in the homeland of spectacular scenes. Which country would provide a better stage than America, if it is meant to arise the challenged role of architects to intellectual stars. In the land, where architecture has been read more vertical than horizontal OMA could experiment his design-methods excellently based on the section. Since 


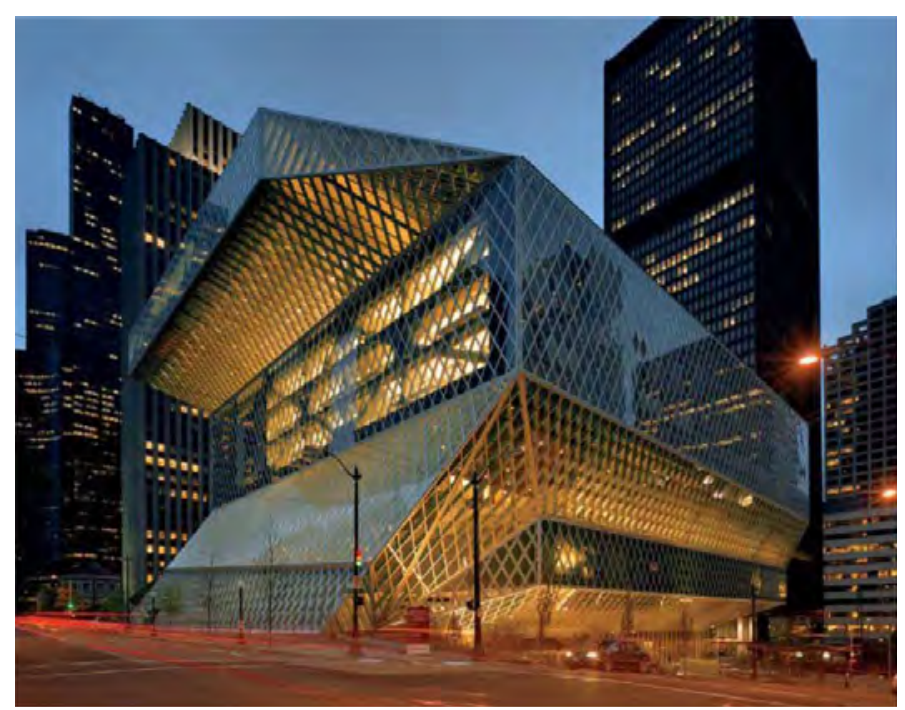

Figure 2. Seattle Central Library.

Koolhaas doesn't see much difference between the two professions script writing and architecture (Fig. 2):

"In both you have to "consider a plot, develop episodes, create a kind of montage, that makes it interesting."14

Koolhaas' roots in script writing emerge not only in the way of designing buildings but also in the architecture theory of OMA, often in the form of dramatic introductions like in the description about the Seattle Central Library:

"The library represents, maybe with the prison, the last of the uncontested moral universes ${ }^{15}$...The library stands exposed as outdated and moralistic at the moment that it has become the last repository of the free and the public." ${ }^{16}$

Like in many other OMA-projects the section prodrudes in the design emergence process, supported by the diagrammatic visualization of relevant data. There is a comprehensible relation between the sectional illustration of media-history as an initial point and the diagrammatic clustering of the program. The staging of architectural program in films has often occurred as sectional readings or $x$-ray elevations of facades. The complexity of urban life has been presented behind bounteous glas perpendicular to the vertical axis. Different, alike or contradictory images were added horizontally as well as vertically, separated by walls and interconnected territorial within the collective enclosure. It is not astonishing that this kind of reading and displaying of architecture comes in the work of Koolhaas, a former script writer, in force. Diagrams as preliminary stage induce the section, which allow an abstract reading of the program. The transformation from the twodimensional section to the three-dimensional object can be achieved rationally or happens intuitively. In the case

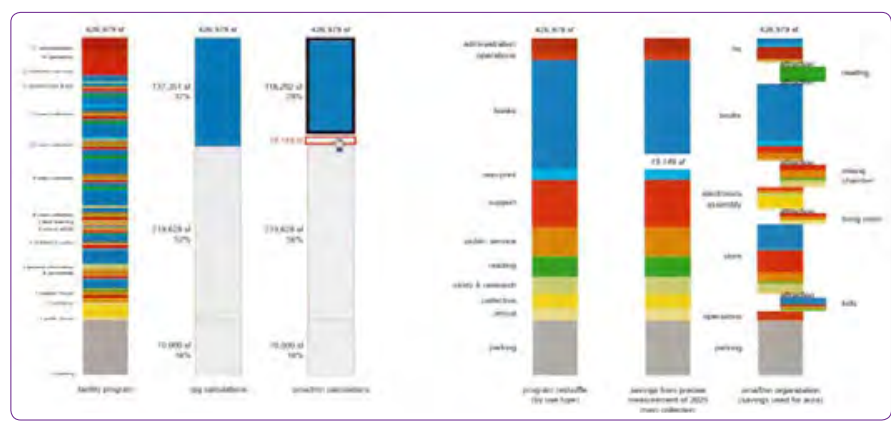

Figure 3. Seattle program diagram.

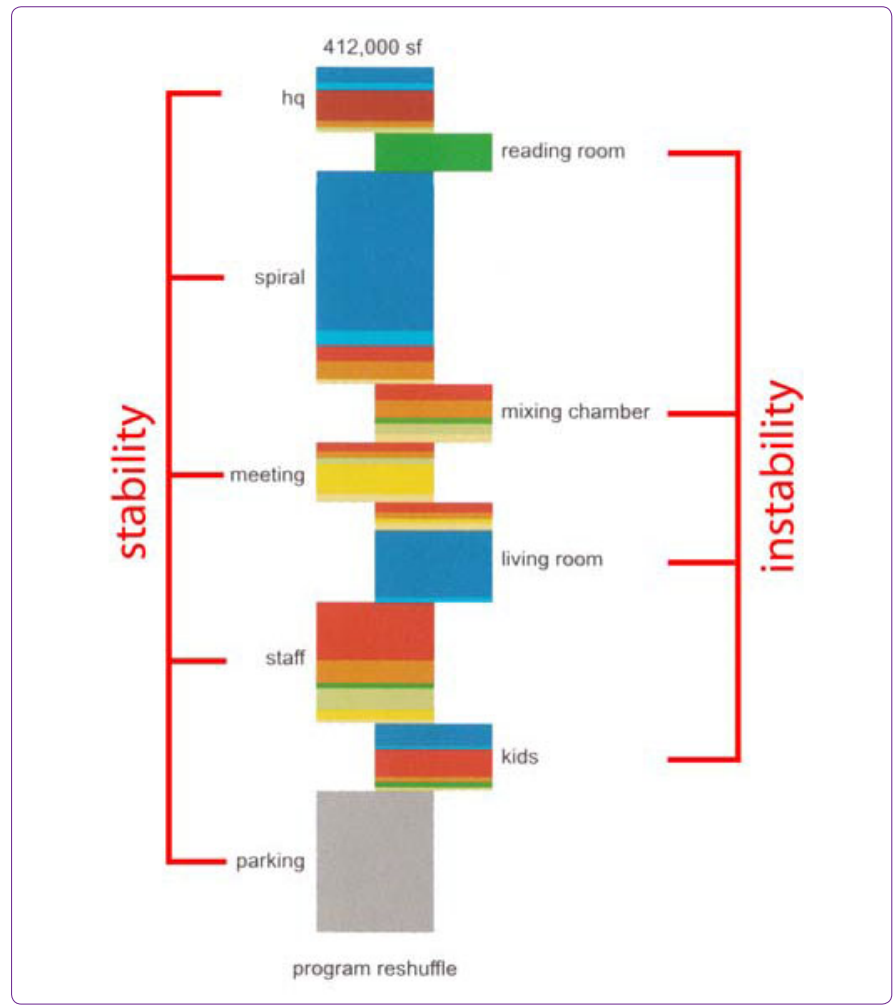

Figure 4. Clusters of stability and instability.

of the Seattle Central Library the design approach will be classified as "highly highly rational" (Fig. 3).

After "combing" the programs and media, similar ones were put together for the purpose of programmatic clusters. Then OMA categorized these nine clusters into two groups: one of stability and the other of instability (Fig. 4 and 5).

Instead of an indetermined flexibility of a floor, on which anything can happen, OMA suggests "tailored flexibility" within spatial compartments for specific duties. ${ }^{17}$ While parts like parking, staff, assembly, books, and headquarters define stabile platforms, "kids", "living room", "mixing chamber" and "reading room" are the unstable in-betweens (Fig. 6). 


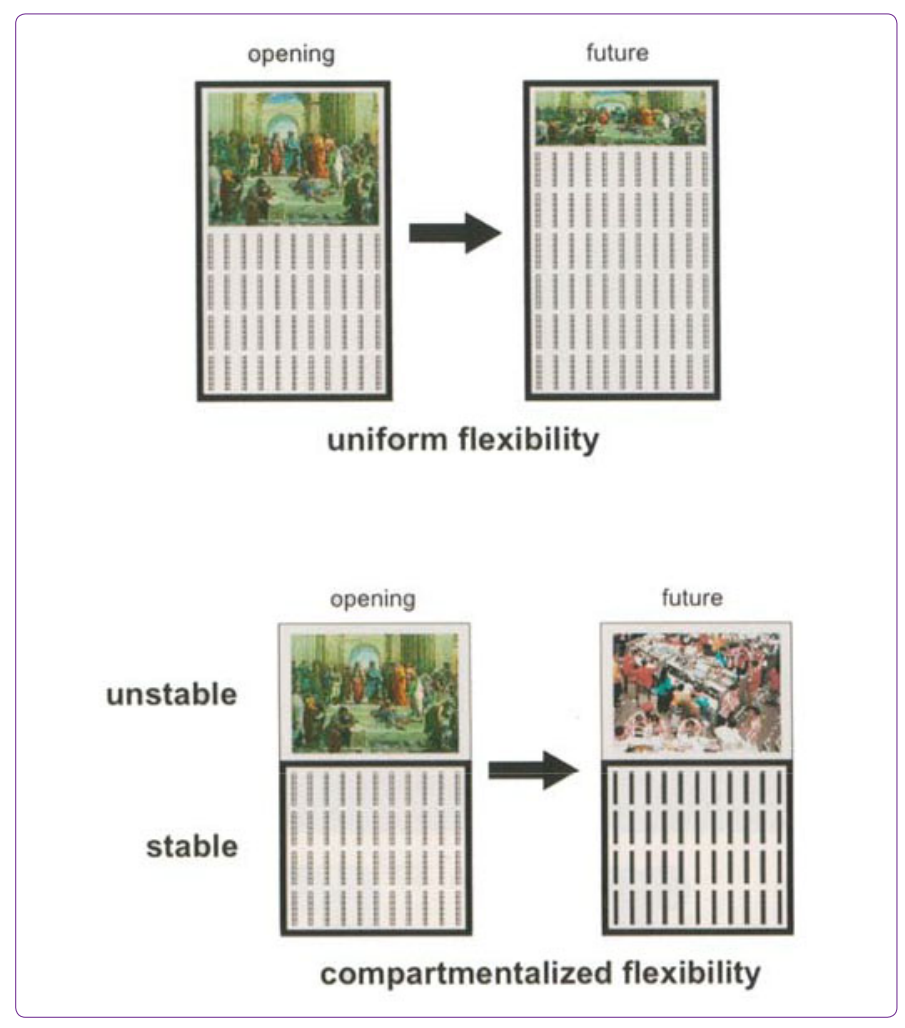

Figure 5. Concept of stability.

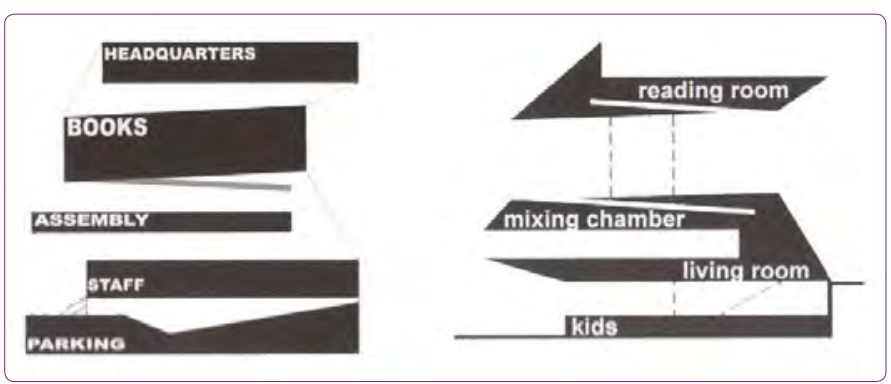

Figure 6. Platforms and in-betweens.

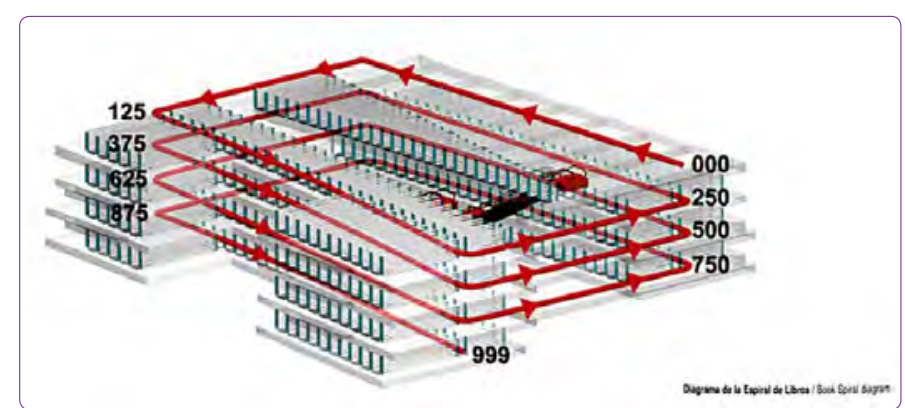

Figure 7. Bookcases.

The floors are shifted in order to get areas with different light conditions, facades reacting to the surrounding site conditions and pretentious form language. The books in the library are not divided in floors or categories, but arranged in a continuous spiral which connects different levels together (Fig. 7).
“For Seattle, the Spiral's 6,233 bookcases are guaranteed to house 780,000 books upon opening, with the flexibility to add 1,450,000 books in the next future (without adding another bookcase). ${ }^{18}$

\section{Emptiness in the Concept of Seattle Central Library Diagrammatical Emptiness}

As diagram \& section are the primary tools of OMA's production of architectural concepts, they generate easily interpreted graphics of the principle idea of designing emptiness.

After accumulating and combining the original program in the form of a simple skyscraper, programs will be shifted, not only in order to differentiate between stable and unstable, but also between solid and void. It is meant to transfer the void from outside to the inside of the enclosure. The conviction or fantasy of programming emptiness and imagining nothingness is aspired through a horizontal scissor operation in the section. Here the parallelism to Koolhaas urban programmatic densification idea without the insertion of substance recurs.

The physical absence of architectural containments as well as the extension of perceptible territorial borders as a result of conscious abstinence, enable to implement a set of activities and programmatic density without the dominance of substantial interventions. The scissor operation generates additional horizontal as well as vertical boundaries, which constitute the minimum necessary definition of spaces as the physical identity of programs. The method of emptying raises the quantity of invention fields, between building and its surrounding. While on one side the air space will be brought into the building, on the other side the outdoor space will be defined through new surfaces. Consequently The Seattle Central library is woven formally more interactive to its milieu (Fig. 8 and 9).

By shifting the unstable clusters horizontally the relations and intersections of programs still remain but are enriched by empty spaces, which allow a multitude of interactions between the clusters and for the evolution of the programs. The "word section" on Fig. 9 displays intelligibly the aim of keeping certain areas empty. While the corpus of the space between the clusters and the enclosure is filled by functions accurately, an empty block crosses through the building in the $z$ axis. This generosity of space is also underlying the idea of making a building public. Public spaces mostly associate within the urban fabric empty areas like plazas, parks, an opposite of the built city. By using emptiness and expanding the borders of perceived space, OMA creates the atmosphere of public space within the building (Fig. 10).

\footnotetext{
${ }^{18}$ Koolhaas, 2004, p. 142
} 


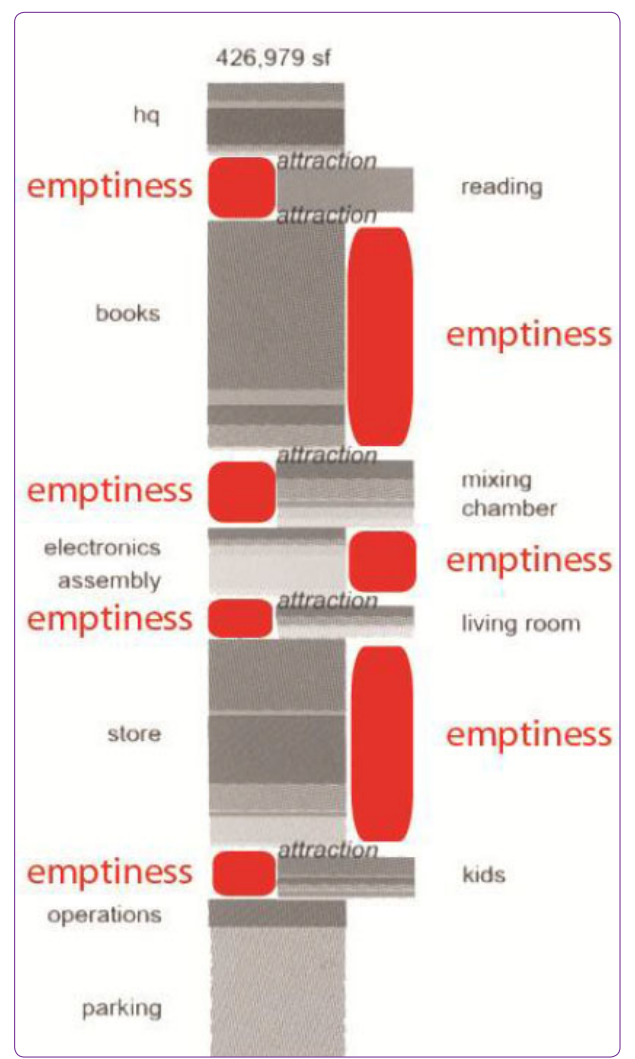

Figure 8. Emptiness in the program.

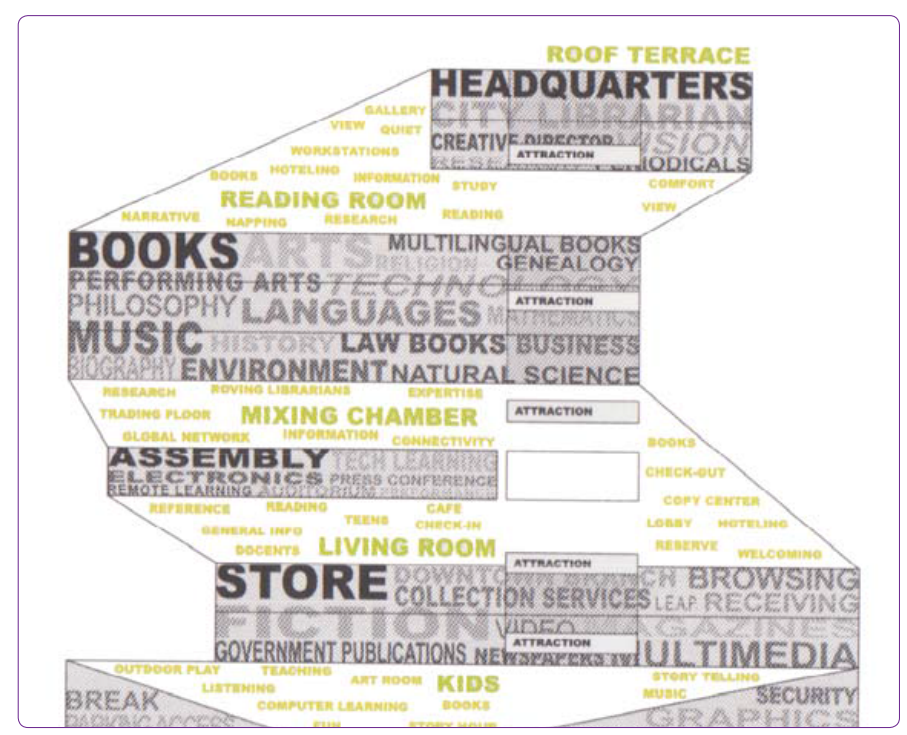

Figure 9. Word and Void.

Next to the floors, which make each converge to the other by open swinging ramps, emptiness marks a second linking element, creating the boundless visual ascertainability of areas within each floor and even different levels. In specific areas emptiness seems to dominate and dwarf the program. Instead of isolating borders, the manifold functions within an enclosing and unifying skin are defined by furnitures or installations. Bounteous dis- tances between the mentioned program islands provide an individual occupancy of space without affecting the atmosphere of an generous public. Public means in a sense also emptiness. Since the free accessibility only of a space doesn't imply the necessary attractiveness for the community. The feeling of acceptability demands also an offer of empty space. Emptiness is not only symbolizing grandness but also generousness. Both are essential attributes of a favored state. Emptiness in a desired space means magnanimity. As Koolhaas tries to practice the idea of not only making a public building, but also making the building public, this concept causes the side effect, that certain amount of empty space has to be provided. Floor areas equal to plaza sizes, ceiling heights approach building dimensions. The phenomenon bigness results out of this ne-

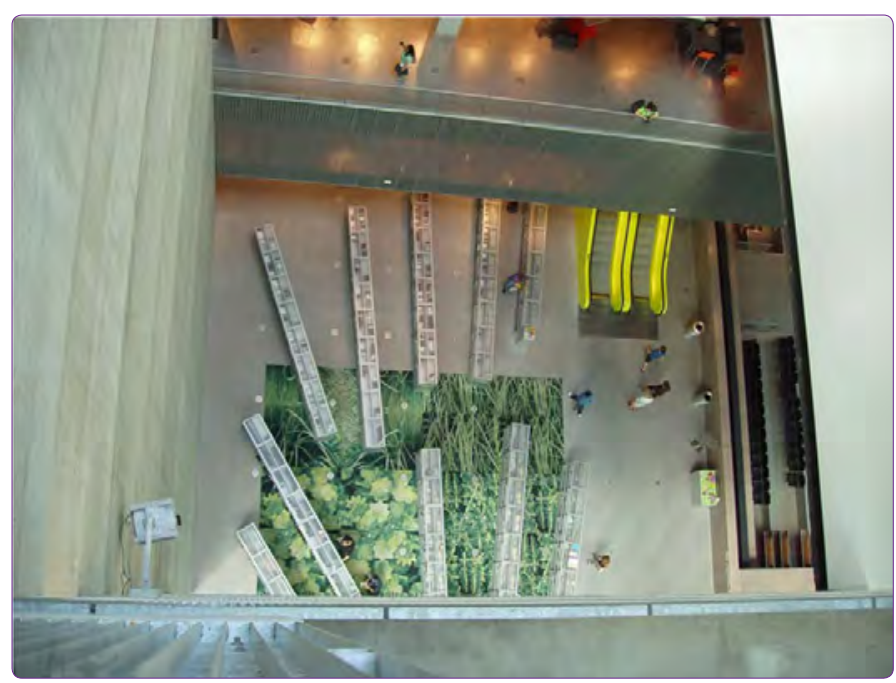

Figure 10. Vertical Emptiness.

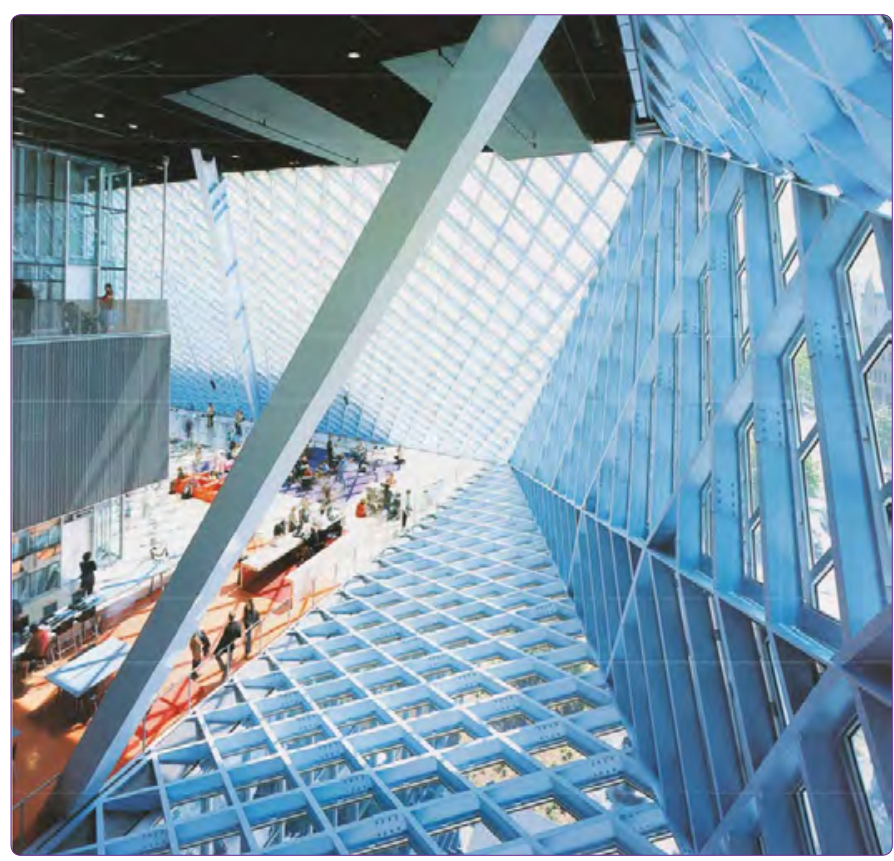

Figure 11. Between program and skin. 


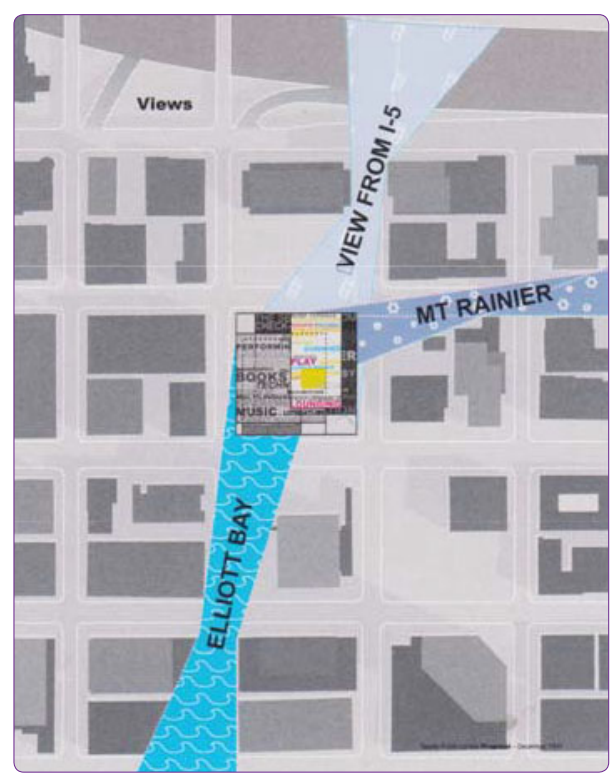

Figure 12. Surrounding.

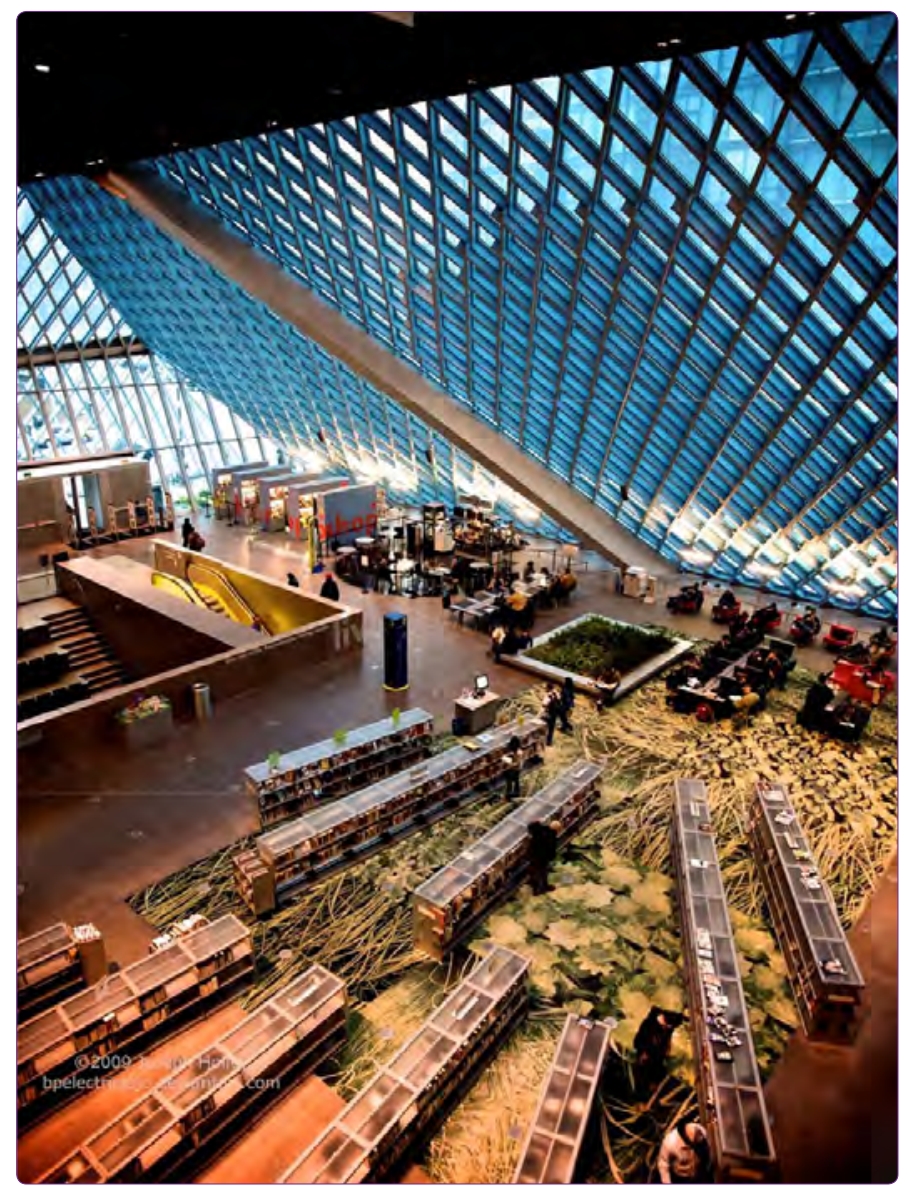

Figure 13. View to the Facade.

cessity of emptiness. In every In-between zone, there is an abyss of human proportion got lost on the endless floor, and the overwhelming dimension of the skin construction. While furniture dispersed on the floor relates to human proportions, steel elements of the enclosure betray the emerged antagonism. The bigger and freer the floor area is, the more back-breaking seems the skin (Fig. 11 and 12).

Another interesting aspect of the Seattle Central Library is that the emptiness between the enclosure and the program enables a phenomenon which normally prevails for the relationship of the facade with its surrounding. Fig. 12 Surrounding OMA shows perspectives of the facade from different sites and corners of the streets. The visibility of the perceivable facade depends on the distance between viewpoint and facade. Interesting is, that through the volume of emptiness in the interior, the enclosure of the space steps back so far that the façade becomes also iconic from the inside (Fig. 13).

Visitors can look from galleries, which are situated in the bounteous emptiness between program and skin and perceive the angular facade. Thus the façade becomes background and protagonist at the same time.

In this coherence it is worth the mention that it cannot be a fortuity that Koolhaas deals highly sensibly with materials while basing his design concepts on emptiness. Both topics, emptiness and materiality complement one another. If emptiness induces bigness in proportions, materiality gets an enormous relevance. Floor areas as well as the enclosure demands elevated attentiveness. The scale of used materials is often adapted to the building size. Some of the patterns are only recognizable from the proper perspective and distance. In summary the bigger the emptiness is, the bigger is the enclosure and the importance of materiality.

\section{Emptiness of Articulation}

As mentioned before OMA applies the vocabulary of contradictions as an architectural method and constructs episode of scenes, which show together a narrative composition. To arrange and intensify the effect of materials and images, aphasic areas are created. Nearly naked ceilings, minimalistic lamps and untreated reinforced concrete produces a lack of perception and an emptiness of articulation which are filled in other parts, like the red curved staircase (Fig. 14 and 15).

The conscious abstinence in certain parts of the Seattle Central Library enables and balances the extravagance in other elements like in the case of some stairs. The manifold program of the library is supported by the different scenes, loaded with erratic atmospheres which arise the experience of the library to an exciting montage of episodes.

\section{Strategy of the void - Très Grande Bibliothèque}

Due to the fact that OMA's Très Grande Bibliothèque has not been built, the spatial analysis cannot be as detailed as in the realised Seattle Central Library. Nevertheless the strategy of void in this competition contribution of OMA definitely confirms the analysis of this paper. 


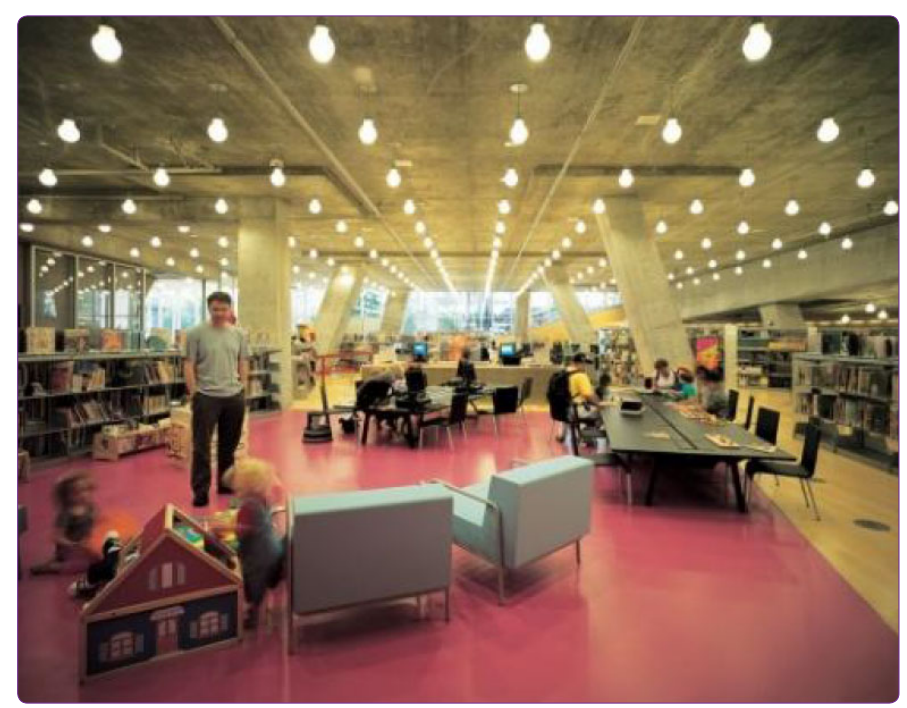

Figure 14. Minimalistic ceiling Lamps.

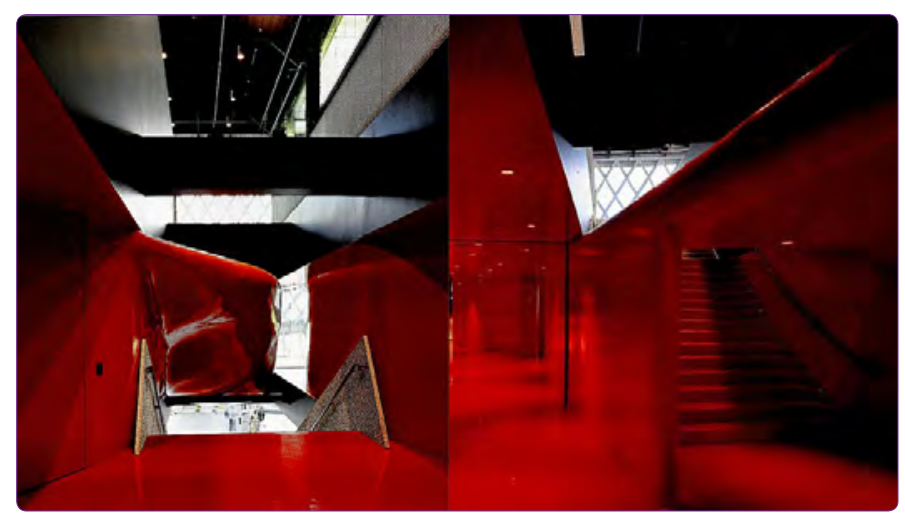

Figure 15. Stairs.

As mentioned before in the Seattle Library, diagram and section are the primary tools for the concept. Whereby here the role of the diagram is replaced by the plan while the section keeps its elementary role. The formula of the concept for the Très Grande Bibliothèque in Paris is summarised as the plan = the section. In the design process of the Seattle Library systematic shifting of the solid blocks in the section created the empty areas. Whereby in the Très Grande Bibliothèque the voids are taken out from the solid block. Here void/emptiness is obviously the protagonist of the imagined scenario: voids breaking through the solids horizontally as well as vertically. OMA describes the empty areas (absence of building) as the most important parts of this building.

"Imagine a building consisting of regular and irregular spaces, where the most important parts of the building consist of an absence of building. The regular here is the storage." ${ }^{19}$

Further this design approach is related to the digital revolution. Since in Très Grande Bibliothèque in Paris the idea

\footnotetext{
${ }^{19}$ Koolhaas, Bruce, Mau, 1995, p. 626.
}

of emptiness is represented as an architectural tool of the electronic revelution, "the melt of solid, the elimination of physical embodiment."

In 1989 the french government organized a competition for the national library in Paris at the Seine, on a site with 350x275 meters. The "megalomaniac" bibliotheque programm with $250.000 \mathrm{~m}^{2}$ aimed to collect the entire production of words and images after 1945. Très Grande Bibliothèque consisted of five autonomous and "identifiable" libraries with varying properties and requirements: library for all visual images, clips and movies which have been produced since 1945, library for recent acquisitions, the third as a reference library, a library for all edited catalogues and the fifth as a scientific research library.

From the very beginning of the design process OMA considered the program as two main contrasting elements: the storage and the social/public areas. Thus they started the design process by trying to construct methods for the design of public spaces within the main function of storages. During the early stages the different libraries were sketched as unique geometries floating over an enormous horizontal storage block. Further the idea of a highrise building occurred and first concept models and sketches of a building with more than $100 \mathrm{~m}$ height were debated. In this concept the libraries constituted levels and terraces instead of uniq detached buildings.

\section{Emptiness As Collective/Public Space}

Suddenly, a sketch, which had been produced for a different scheme became very "stimulating" and "acquired an amazing appropriateness" to solve the complex dilemma of the concept. This sketch demonstrated a way to manage the public spaces as gaps and voids, as empty spaces, which could be left out within the "solid mass of boring utilitarian substance. So the aim became to invent the most important parts of the building in a passive manner, in the method of living out. The empty spaces, described as "the absence" were defined as the public spaces for visitors within the "solid block of information".

OMA summarises the concept of the library, which received an honorable mention, in following sentence:

"The library is imagined as a solid block of information, a dense repository for the past, from which voids are carved to create public spaces - absence floating in memory."20

The public spaces are the special voids concepted as flexible escapes or conscious oblivion of rational organised utilitarian obligatory spaces. Like in the Seattle Library, OMA creates the atmosphere of public space within the building, by using emptiness and expanding usual borders horizontally as well as vertically.

\footnotetext{
${ }^{20} \mathrm{http}: / /$ oma.eu/projects/tres-grande-bibliotheque [Erişim tarihi 24 Ekim 2017].
} 


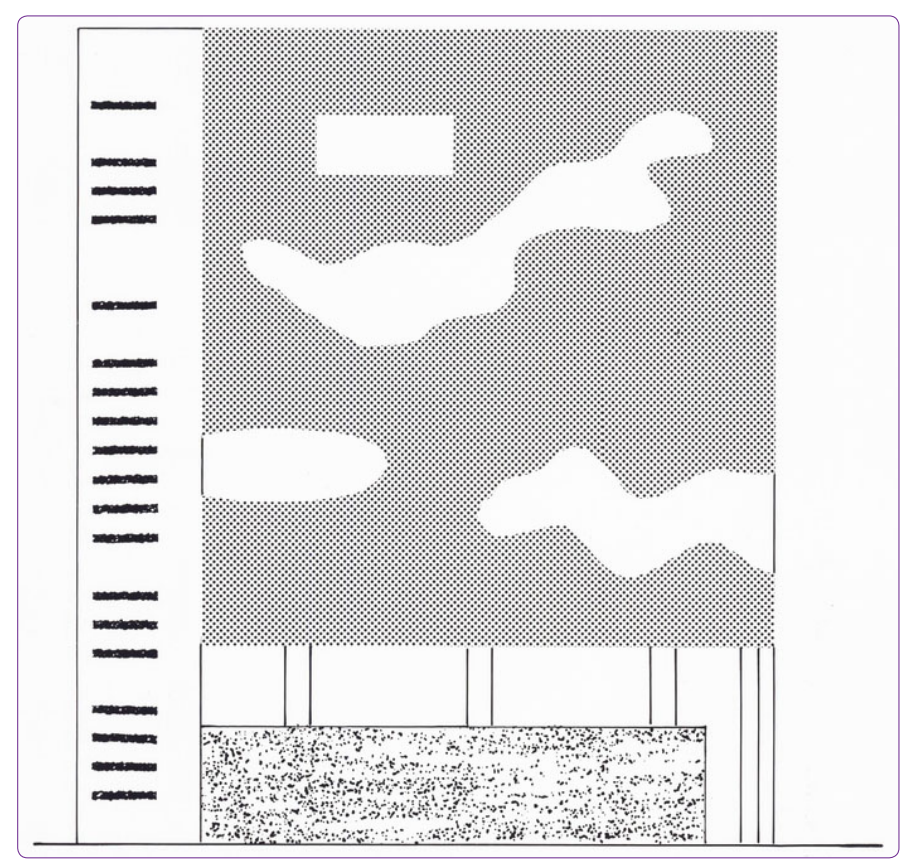

Figure 16. Section.

"In this block, the major public spaces are defined as absences of building, voids carved out of the information solid. Floating in memory, they are multiple embryos, each with its own technological placenta." ${ }^{21}$

OMA positioned nine elevator shafts into the plan of a $100 \times 100 \mathrm{~m}$ block of storages. One façade was reserved for the offices. Then they carved out voids in different levels and positions according to the requirements of the public areas. Those which needed roof light were situated at the top, those which required a panorama next to the fassade, the necessarily dark ones to the centre of the block and the most visited ones next to the ground floor and the entrance.

"The TGB is a cube. It is solid storage with the reading rooms - voids - excavated where efficient. Dark in the center, daylight on the perimeter. Crowds below, empty chambers above for reflexion." 22

Those from the storage mass substracted multileveled voids of the public spaces created sophisticated three-dimensional spaces, which, according to Koolhaas, would have been very difficult built forms, but became easy in the opposite method of thinking, as the absence of the built.

Koolhaas believed that this concept contained great future and great potential, for example by enabling simplicity and flexibility for the library. The huge voids breaking through the grids of endless storages defined territories of functional freedom. The five libraries were characterized by urban bubbles reaching up to nine meters, ready to take off but still anchored in the sea of media (Fig. 16).

\footnotetext{
${ }^{21}$ Koolhaas, Bruce, Mau, 1995, p. 616. ${ }^{22}$ Koolhaas, Bruce, Mau, 1995, p. 628
}

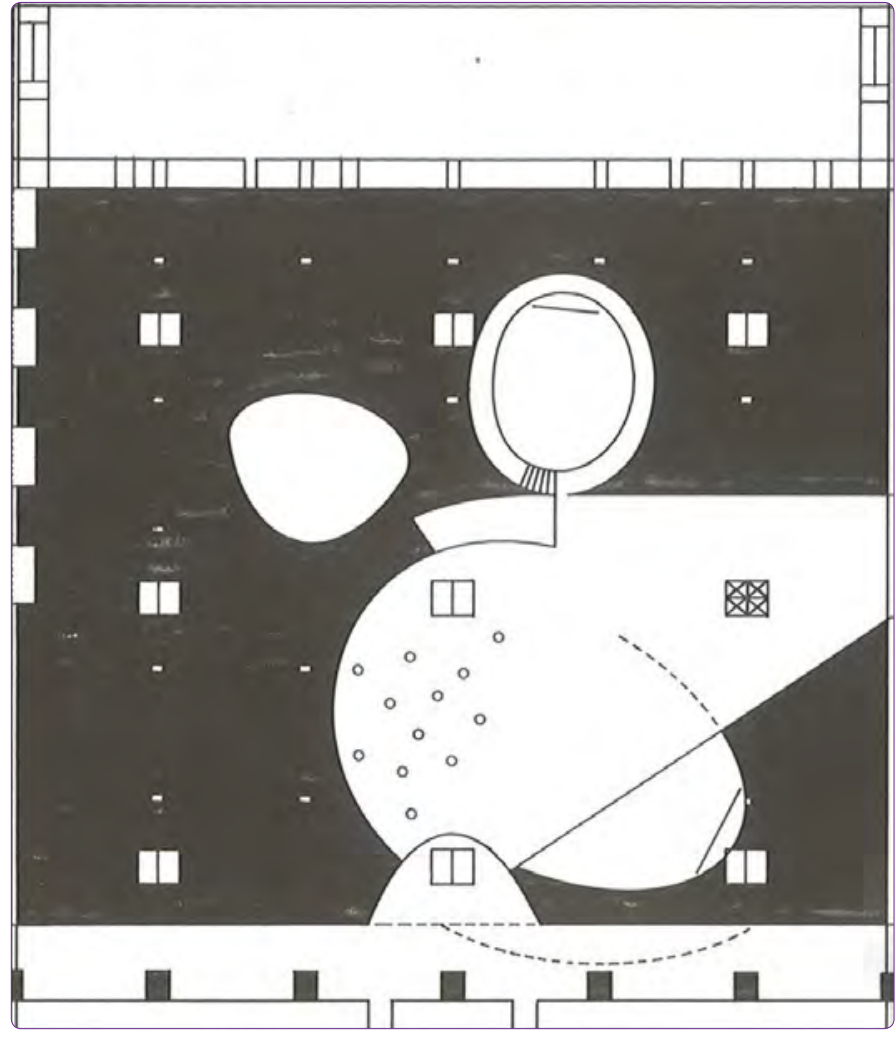

Figure 17. Plan.

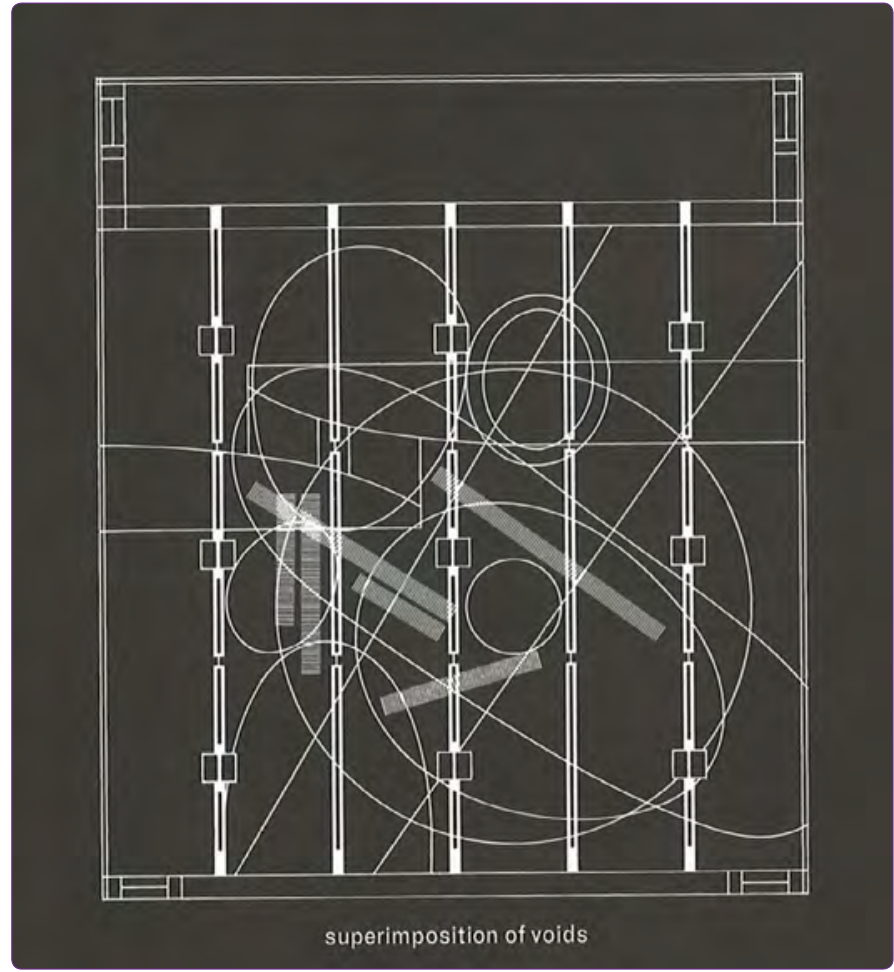

Figure 18. Sperimposition of voids.

As the Figures 16 and 17 demostrate, the section drawing and the plan display major similarities. The concept of dynamic irregular voids of collectivity within the irremove- 


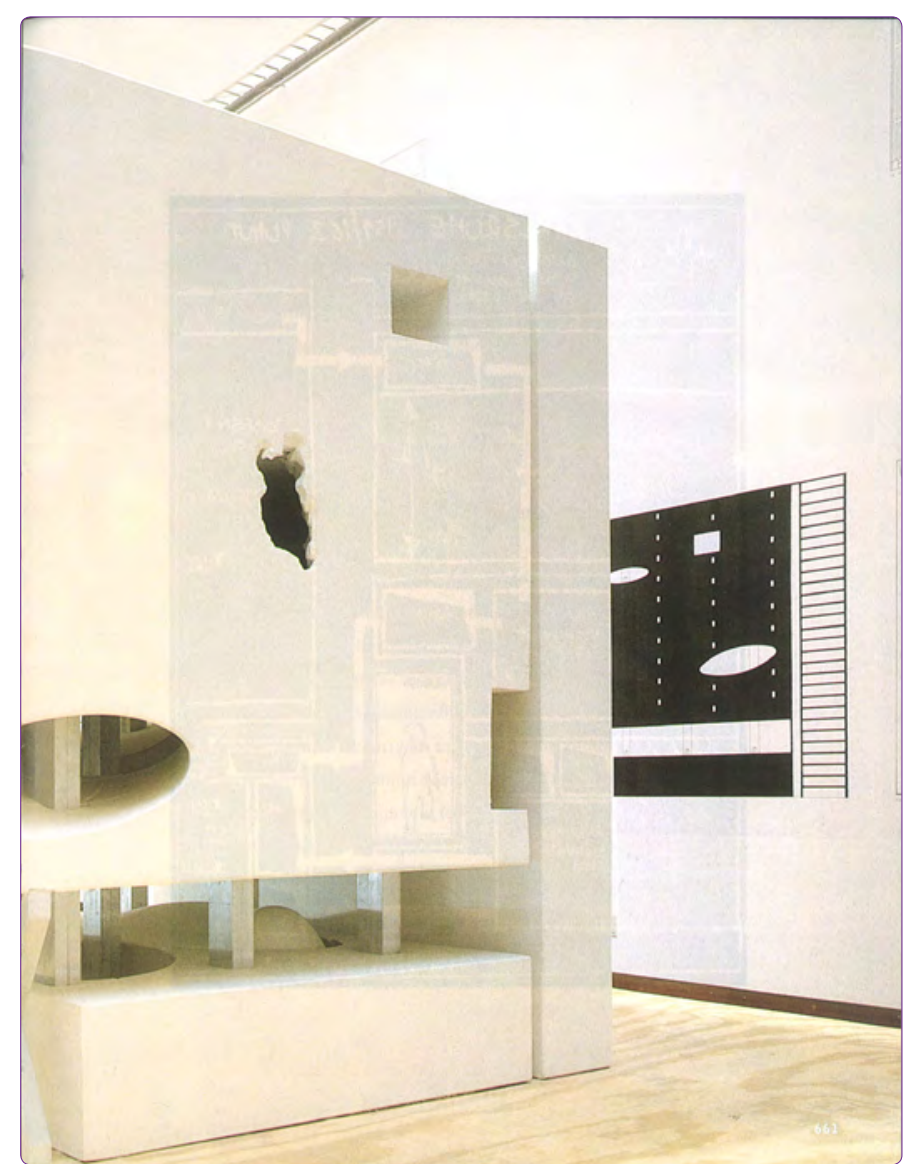

Figure 19. Modell of voids.

able regular storage mass continued in the horizontal as well as in the vertical axis. This conceptual unanimity was formulated for the TGL project as: "The Plan = The section"

The concept for the statics played an important role for this formula. The floor was divided in eight narrow strips with each 12.5 meter width (maximum area according to the regulation of fire compartments). On the borders of these stripes $80 \mathrm{~m}$ high concrete walls reached through the entire height of the building by providing certain openings in different scales transcending the borders of floors. So the voids in these walls completed the concept of absence in the vertical section.

In the plan 9 regular vertical circulation shafts are situated. Each level, in which these regular vertical shafts are embedded by the void, offers an access. In other words "As long as a void surrounds one of the elevator squares, it is accessible." In order to underline the idea of void, some floors and ceilings are covered by glass as the transition from void to solid.

"The organization of the building is most explicit in the Great Hall of Ascention, a horizontal cut separating the lower four floors from the cube that hovers nine meters above. The hall can receive 10,000 people; its floor and ceiling are made of glass."

\section{Emptiness as Identity}

The theme of enclosure or shell, which unified the diagrammatic sections of the Seattle Library, plays an important role in the form of the voids in Très Grande Bibliothèque. The façade is plane with transparent, translucent and opaque elements. It reveals sometimes the interior of the library, sometimes it allows just an impression or it hides the interior. But it underlines the curved voids within the orthogonal solid blocks. Curved geometries, similar to bubbles lighten the monumental voids in urban scale. Despite the minimalistic form of the main block, these visible voids award the library an outstanding image. They do not only challenge the repitative solids of the residential blocks next to the site but also the reluctant image of libraries. The voids on the façade open up a new understanding of openings according to the urban scale of the building.

Très Grande Bibliothèque had two major tasks: Primarily to change "the image of the libraries as formless architecture" and secondarily to create difference, which is an "unbearable" task of competition projects. The concept of voids, converted these difficult tasks to an affordable amusement.

"The creation of difference, the unbearable task becomes plesure. Easy too. Forms only have to be "left out," not constructed." (Fig. 19).

\section{Conclusion}

"What is solid has melted, what is void floats in nothingness." ${ }^{23}$

Nothingness is defined as the unthinkable field in the pre-Socratic time as well as in analytic philosophy of the $20^{\text {th }}$ century. The first question was, why does Rem Koolhaas uses this philosophical problematic term in his architecture theory? This analysis shows that Koolhaas intention is not to confute Parmenides but the methodology of formulating - in theory as well as in architectural practice - in dualities or even (problematic) contradictions. Well aware of the borders of logic - probably exactly because of this border - he brings these two words together. Imagining and nothingness. The verb imagining symbolises the difficulty of rethinking architectural dominance in today's cities and nothingness the desire of empty spaces which can be charged and animated by contemporary programs. Thus nothingness means space as architectural program without the necessity of construction. The second research question was the relation between nothingness and emptiness. If nothingness defines architectural space as a created programm, the term nothingness requires the term emptiness. Emptiness enables the movement, in architectural meaning a space which can be programmed,

\footnotetext{
${ }^{23}$ Koolhaas, Bruce, Mau, 1995, p. 628.
} 
charched by social activity or a set of meaning of the present. Thus Democritos as well as Rem Koolhaas uses emptiness for en entity which enables the idea of movement. The relational reading of Rem Koolhaas buildings with philosophical terms, which Koolhaas also uses in his theories, enable to analyse if these terms also influence the design approach of OMA.

This analysis unveils the potential of philosophical terminology for architectural theory and design theory in different scales as well as dimensions. In Koolhaas'work terms like nothingness / absence / emptiness / void occure at first in the theory. Furthere they begin to find meaning in the design process, in graphics, sections, plans and models. Finally they become embodied in materials, facades or spatial intersections. In the analysed libraries the term void / absence represents Koolhaas' idea of public space. The voids become visible at the façades of the building. The idea of void in urban scale transforms the metropolitan identity with the abolution of usual opening sizes and the transformation of façades. In the spatial analysis the term emptiness helps to read the perceptible intensity of OMA's architectural script. Spatial expressions vary between intensive articulation and muteness.

Last but not least the contribution of this paper enables to read further OMA projects. To give here some inspirations: In Casa de Musica (1999-2005) carving outs in the form of sharp geometries play again essential role for creating the new image of a concert hall. In the KaDeWe the four courts are oriented and arranged around four core voids "acting both as a main central atrium and a primary vertical distribution space." In the CCTV tower the central void as the most elementary part of the concept, framed by the loop, enables "an alternative to the exhausted typology of the skyscraper."

\section{References}

Cansever, T. (2009) Islam'da Şehir ve Mimari, Istanbul, Timaş yayınları

Cecilia, F. A., Levene, R., (2007) OMA, Koolhaas, Madrid, Elcroquis editorial

Grünwald, M. (1949) Die Anfänge der abendländischen Philosophie, Zürich, Artemis Verlag

Koolhaas, Bruce, Mau, (1995) S, M, L, XL, New York, Monacelli Press

Koolhaas, R., AMOMA, (2004) Content, Köln, Taschen

Lucan, Jacques Ed., (1990) OMA, Rem Koolhaas, Mailand und Paris, Electa France,

\section{Internet References}

www.oma.eu [Erişim tarihi 24 Ekim 2017]

http://oma.eu/projects/tres-grande-bibliotheque [Erişim tarihi 24 Ekim 2017] http://www.flsfdergisi.com/sayi7/107-120.pdf [Erişim tarihi 31 Ekim 2017]

http://www.notablebiographies.com/news/Ge-La/KoolhaasRem.html [Erişim tarihi 31 Ekim 2017]

http://www.kfs.org/ jonathan/witt/ten.html [Erişim tarihi 31 Ekim 2017]

http://www.seattlepi.com/ae/article/On-Architecture-New-library-is-defining-1176959.php [Erişim tarihi 31 Ekim 2017]

\section{Film References}

Heidingfelder; Markus, TESCH, Min, REM KOOLHAAS, A kind of Architect, absolut media, arte edition

\section{Table of Figures References}

Fig. 1 Surrender: Koolhaas, Bruce, Mau, (1995) S, M, L, XL, New York, Monacelli Press, p. 972.

Fig. 2 Seattle Central Library: http://www.architravel.com/fi les/ buldingsImages/bulding29 7/Seattle_Central_Library_1.j pgBeispielabbildung 12.10.201.

Fig. 3 Seattle diagramm programm: Cecilia, F. A., Levene, R., Oma, Koolhaas, R. 1996/2007, Madrid, Elcroquis editorial, p.72.

Fig. 4 Clusters of stability and instability: Koolhaas, R., AMOMA, (2004) Content, Köln, Taschen, p. 140.

Fig. 5 Concept of stability: Koolhaas, R., AMOMA, (2004) Content, Köln, Taschen, p. 140.

Fig. 6 Platforms and in-betweens: Koolhaas, R., AMOMA, (2004) Content, Köln, Taschen, p. 141.

Fig. 7 Bookcases. Koolhaas, R., AMOMA, (2004) Content, Köln, Taschen, p. 142.

Fig. 8 Emptiness in the programm: Additional illustration by the author.

Fig. 9 Word and void: Cecilia, F. A., Levene, R., Oma, Koolhaas, R. 1996/2007, Madrid, Elcroquis editorial, p. 72.

Fig. 10 Vertical Emptiness: http://www.flickr.com/photo s/ truusbobjantoo/293493481 1/sizes/o/in/photostream/ 13.10.2011.

Fig. 11 Between program and skin: Cecilia, F. A., Levene, R., Oma, Koolhaas, R. 1996/2007, Madrid, Elcroquis editorial, p. 93.

Fig. 12 Surrounding: Koolhaas, R., AMOMA, (2004) Content, Köln, Taschen, p. 142.

Fig. 13 View to the facade: http://bpelectricjojo.deviantar t.com/ art/Seattle-Central- Library-155128297 14.10.2011.

Fig. 14 Minimalistic sealing and lamps: http://de.urbarama.com/ proje ct/seattle-central-library 15.10.2011.

Fig. 15 Stairs: http://de.urbarama.com/projec t/seattle-centrallibrary 15.10.2011.

Fig. 16 Section: http://oma.eu/projects/tres-grande-bibliotheque [Erişim tarihi 24 Ekim 2017].

Fig. 17 Plan: Koolhaas, Bruce, Mau, (1995) S, M, L, XL, New York, Monacelli Press, p. 605.

Fig. 18 superimposition of voids: Koolhaas, Bruce, Mau, (1995) S, M, L, XL, New York, Monacelli Press, p. 659.

Fig. 19 modell of voids: Koolhaas, Bruce, Mau, (1995) S, M, L, XL, New York, Monacelli Press, p. 661. 